\title{
Systemic anti-inflammatory mediators in COPD: increase in soluble interleukin 1 receptor II during treatment of exacerbations
}

M A Dentener, E C Creutzberg, A M W J Schols, A Mantovani, C van't Veer, W A Buurman, E F M Wouters

\begin{abstract}
Background-The aim of this study was to test the hypothesis that the chronic inflammatory process present in chronic obstructive pulmonary disease (COPD) is due to a defective endogenous antiinflammatory mechanism.

Methods-Systemic levels of the antiinflammatory mediators soluble interleukin 1 receptor II (sIL-1RII), soluble tumour necrosis factor receptor p55 (sTNF-R55) and sTNF-R75, and of C reactive protein (CRP) and lipopolysaccharide binding protein (LBP) were analysed in 55 patients with stable COPD (median forced expiratory volume in one second $\left(\mathrm{FEV}_{1}\right) 34 \%$ predicted (range $15-$ 78)) and compared with levels in 23 control subjects. In addition, changes in these mediators were studied in 13 patients with COPD (median FEV $34 \%$ predicted (range 19-51)) during the first 7 days in hospital with an exacerbation of the disease.
\end{abstract}

Department of Surgery, Maastricht University, Nutrition and Toxicology

Research Institute Maastricht

(NUTRIM), $6202 \mathrm{AZ}$

Maastricht, The

Netherlands

M A Dentener

E C Creutzberg

A M W J Schols

C van't Veer

W A Buurman

E F M Wouters

Department of Immunology and Cell Biology, Instituto di Ricerche

Farmacologiche Mario Negri, Milan and Department of

Biotechnology, Section of General Pathology,

University of Brescia,

Italy

A Mantovani

Correspondence to: Dr M A Dentener Mieke.Dentener@ pul.unimaas.nl

Received 27 September 2000 Returned to authors 14 December 2000 Revised version received 19 April 2001

Accepted for publication

8 June 2001
Results-Patients with stable COPD were characterised by a systemic inflammatory process indicated by an increased leucocyte count $(7.2(4.7-16.4) v 4.8(3.5-8.3) \times$ $\left.10^{9} / 1\right)$, raised levels of CRP (11.8 (1.1-75.0) $v 4.1(0.6-75.0) \mu \mathrm{g} / \mathrm{ml})$ and LBP (45.6 (8.1$200.0) v 27.9(14.1-71.5) \mu \mathrm{g} / \mathrm{ml})$, and modcontrast, the sIL-1RII level did not differ between patients and controls (4.53 (2.097.60) $v 4.63(3.80-5.93) \mathrm{ng} / \mathrm{ml})$. During treatment of disease exacerbations, systemic levels of both CRP (at day 3) and LBP (at day 7) were significantly reduced compared with day 1 , whereas SIL-1RII levels increased.

Conclusions-These data suggest an imbalance in systemic levels of pro- and anti-inflammatory mediators in patients with stable COPD. The increase in the anti-inflammatory mediator sIL-1RII during treatment of exacerbations may contribute to the clinical improvement. (Thorax 2001;56:721-726)

Keywords: chronic obstructive pulmonary disease; systemic inflammation; soluble interleukin 1 receptor II

Chronic obstructive pulmonary disease (COPD) is characterised by airway inflammation which is considered to play a pathogenic role in this disorder. ${ }^{1}$ Polymorphonuclear leucocytes $(\mathrm{PMN})$ are present in increased erate increases in both sTNF-Rs. In numbers in bronchoalveolar lavage (BAL) fluid and in sputum. In addition, an influx of macrophages and lymphocytes in the bronchial mucosa and increased levels of the proinflammatory cytokine tumour necrosis factor (TNF) $\alpha$ and the chemokine interleukin (IL)-8 have been observed in the sputum of patients with COPD. ${ }^{2}$ In the circulation increased levels of inflammatory markers such as $\mathrm{C}$ reactive protein (CRP) and lipopolysaccharide binding protein (LBP), the soluble TNF receptor p55 (sTNF-R55), and soluble adhesion molecules have been reported. ${ }^{13}{ }^{4}$ Exacerbations of COPD are associated with alterations in the inflammatory profile as indicated by sputum and bronchial mucosa eosinophilia. ${ }^{5}$ An increase in both bronchial and systemic inflammation has also been demonstrated. ${ }^{6-10}$ To date, the underlying mechanisms which induce and control the inflammatory process during (exacerbations of) COPD are unknown.

The course of an inflammatory process will be determined by the balance between proand anti-inflammatory mediators. Several naturally occurring cytokine inhibitors are known for the pro-inflammatory cytokines TNF and IL-1. ${ }^{11}$ Two receptors for IL-1 are present on various cells: the type I receptor (IL-1RI) which mediates cellular activation and the type II receptor (IL-1RII) which does not transduce a signal but acts as a decoy receptor. Both IL-1 receptors are present in soluble (s) forms and these soluble receptors inhibit IL-1 in solution. ${ }^{12-13}$ TNF mediates intracellular signalling via two transmembrane receptors: a $55 \mathrm{kDa}$ receptor (TNF-R55) and a $75 \mathrm{kDa}$ receptor (TNF-R75). TNF-R55 is considered to be the principal TNF receptor, although TNF-R75 also mediates some cellular effects of TNF. Soluble forms of both receptors are reported to inhibit the biological activity of TNF. ${ }^{14}{ }^{15}$

It can be speculated that a defective endogenous anti-inflammatory mechanism could contribute to the continuation of the inflammatory processes observed in COPD. In the present study the systemic levels of the anti-inflammatory mediators sIL-1RII, sTNFR55, and sTNF-R75 were therefore studied in patients with stable COPD and compared with levels in control subjects. In addition, the changes in these inhibitors were studied in a group of patients admitted to hospital with an acute exacerbation of COPD. To assess the systemic inflammatory response, the acute phase proteins CRP and LBP were analysed. 


\section{Methods}

STUDY POPULATION

Patients with stable COPD

The study group consisted of 55 patients consecutively admitted to a pulmonary rehabilitation centre. COPD was defined as forced expiratory volume in one second $\left(\mathrm{FEV}_{1}\right)<80 \%$ predicted for age and height, $\beta_{2}$ agonist reversibility of $<15 \%$ or $200 \mathrm{ml}$, with airflow obstruction evidenced by a ratio of $\mathrm{FEV}_{1}$ to forced vital capacity (FVC) of $<70 \% .{ }^{16}$ Patients with concomitant confounding diseases such as diabetes mellitus, lung carcinoma, thyroid and cardiovascular disease and those with bronchiectasis were excluded from the study. Only patients in a stable clinical condition (who had not suffered from a respiratory tract infection during the previous 6 weeks) and without clinical signs of oedema were included.

Patients with an exacerbation of COPD

This group consisted of 13 subjects consecutively admitted to hospital suffering from an acute exacerbation of COPD (diagnosed as described above). The presence of an acute disease exacerbation was determined by an independent chest physician and was defined as a recent increase in dyspnoea, cough, and sputum production of sufficient severity to warrant admission to hospital. The patients were treated with a standard protocol of medication, starting immediately after admission to hospital (day 0). Medication consisted of nebulised salbutamol $>20 \mathrm{mg} / 24 \mathrm{~h}$, inhaled ipratropium bromide, intravenous theophylline resulting in a plasma theophylline concentration within the therapeutic range (median (range) $11.1(5.7-21.5) \mathrm{mg} / \mathrm{ml}$ ), and prednisolone. The dose of prednisolone was dependent on body weight and ranged from 50 to $75 \mathrm{mg} / 24 \mathrm{~h}$ during the first 4 days of the exacerbation followed by half the initial dose on days 4-7. In cases with bacterial infection identified by sputum culture, specific antibiotic treatment was given.

\section{Healthy controls}

The healthy control group consisted of 23 subjects aged over 50 years with no evidence of COPD based on questionnaires and lung function testing, randomly selected from a population sample of subjects living in the same area as the patients. They had no acute or chronic disease and were not taking any medication.

The study was approved by the medical ethics committee of the University Hospital Maastricht and all subjects gave their informed consent.

LUNG FUNCTION AND DISEASE SYMPTOMS

$\mathrm{FEV}_{1}$ and FVC were calculated from the flowvolume curve using a spirometer (Masterlab, Jaeger, Würzburg, Germany). Lung function parameters were expressed as percentage of reference. ${ }^{17}$ Blood was drawn from the brachial artery while the subjects were breathing room air. Arterial oxygen tension $\left(\mathrm{PaO}_{2}\right)$, arterial carbon dioxide tension $\left(\mathrm{PaCO}_{2}\right)$, and arterial $\mathrm{pH}$ were analysed on a blood gas analyser (Radiometer, ABL 330, Copenhagen, Denmark). Dyspnoea was scored using a visual analogue scale. $^{18}$

MEASUREMENT OF INFLAMMATORY PARAMETERS An evacuated tube containing EDTA (Sherwood Medical, St Louis, MO, USA) was used to collect blood. Inflammatory mediators were measured in plasma by sandwich enzymelinked immunosorbent assay (ELISA), as described previously. Briefly, for detection of sTNF-R55 and sTNF-R75, monoclonal antibodies MR1-1 and MR2-2 were used for coating and specific biotin labelled polyclonal rabbit anti-human (h)-sTNF-R IgG as detector reagents. ${ }^{19} \mathrm{LBP}$ was detected using polyclonal rabbit anti-rhLBP IgG as coating and biotin labelled polyclonal rabbit anti-rhLBP IgG for detection. ${ }^{20}$ For sIL-1RII measurement plates were coated with monoclonal antibody 8.5 against shIL-1RII and detection was carried out with a biotinylated polyclonal rabbit anti-shIL-1RII IgG. ${ }^{21}$ The CRP concentration was measured by a polyclonal ELISA for which antibodies and standard were obtained from Dako A/S (Glostrup, Denmark). The detection limits of the assays were $100 \mathrm{pg} / \mathrm{ml}$ for both sTNF-Rs and sIL-1RII, $200 \mathrm{pg} / \mathrm{ml}$ for LBP, and $500 \mathrm{pg} / \mathrm{ml}$ for CRP. Streptavidinperoxidase conjugate was obtained from Zymed Laboratories Inc (San Francisco, CA, USA) and the substrate 3,3',5,5'-tetramethylbenzidine was obtained from KPL (Gaithersburg, MD, USA). Absorbance was measured spectrophotometrically at $450 \mathrm{~nm}$ using a micro ELISA autoreader. The leucocyte count was determined using COBAS Micro (Hoffman La Roche, Basel, Switzerland).

ANALYSIS OF DATA

Differences in parameters between study groups were compared using the MannWhitney U test. The Wilcoxon signed rank test was used for comparisons within an individual on days $1,3,5$, and 7 of the exacerbation. Correlations between different parameters were evaluated using Pearson rank correlation analysis. Significance was determined at the $5 \%$ level. Data are expressed as median (range) in the text and tables and as box plots (median, interquartile range, outliers and extreme cases) in fig 1. Data were analysed according to the guidelines of Altman et al $l^{2}$ using SPSS/PC+ Version 7.5 for Windows (SPSS Inc, Chicago, IL, USA).

\section{Results}

PATIENTS WITH STABLE COPD

The characteristics of the patients with COPD in a clinically stable condition and the healthy control subjects are summarised in table 1 . In the control group all pulmonary function parameters were in the normal range. Although $\mathrm{PaCO}_{2}$ in the patients did not differ from the control subjects, $\mathrm{PaO}_{2}$ was significantly decreased. All patients except one were current or ex-smokers compared with 17 of the 23 control subjects. 
Table 1 Characteristics of study subjects

\begin{tabular}{llll}
\hline & $\begin{array}{l}\text { Healthy controls } \\
(n=23)\end{array}$ & $\begin{array}{l}\text { Stable COPD } \\
(n=55)\end{array}$ & $\begin{array}{l}\text { Exacerbations of COPD* } \\
(n=13)\end{array}$ \\
\hline Age (years) & $64(60-72) \dagger$ & $69(41-78) \ddagger$ & $68(54-82)$ \\
$\mathrm{M}: \mathrm{F}$ & $16: 7$ & $55: 0$ & $9: 4$ \\
$\mathrm{FVC}(\%$ predicted) & $119(98-150)$ & $85(47-122) \S$ & $71(26-111)$ \\
$\mathrm{FEV}_{1}(\%$ predicted) & $110(77-147)$ & $34(15-78) \S$ & $34(19-51)$ \\
$\mathrm{FEV}_{1} / \mathrm{FVC}(\%)$ & $73(62-83)$ & $31(15-68) \S$ & $40(21-67)$ \\
$\mathrm{PaO}_{2}(\mathrm{kPa})$ & $11.4(9.2-14.6)$ & $9.4(7.5-13.0) \S$ & $8.6(6.3-10.2)$ \\
$\mathrm{PaCO}_{2}(\mathrm{kPa})$ & $5.5(4.6-6.2)$ & $5.7(4.1-7.6)$ & $6.2(4.5-7.2)$ \\
$\mathrm{pH}$ & $7.41(7.38-7.43)$ & $7.41(7.30-7.50)$ & $7.42(7.34-7.49)$ \\
\hline
\end{tabular}

$\mathrm{FVC}=$ forced vital capacity $; \mathrm{FEV}_{1}=$ forced expiratory volume in one second $\mathrm{PaO}_{2}, \mathrm{PaCO}_{2}=$ arterial oxygen and carbon dioxide tension.

*Patient characteristics at day 1 after admission to hospital for exacerbation of disease.

†Values are median (range), or absolute numbers for sex.

$\neq \mathrm{p}<0.05 v$ healthy controls; $\$ \mathrm{p}<0.005 v$ healthy controls; $\uparrow \mathrm{p}<0.05 v$ patients with stable COPD.

Table 2 Presence of systemic markers of inflammation in patients with stable COPD compared with control subjects

\begin{tabular}{llll}
\hline & $\begin{array}{l}\text { Healthy controls } \\
(n=23)\end{array}$ & $\begin{array}{l}\text { Stable COPD } \\
(n=55)\end{array}$ & $p$ Value $^{\star}$ \\
\hline Leucocyte count $\left(10^{9} / \mathrm{l}\right)$ & $4.8(3.5-8.3) \dagger$ & $7.2(4.7-16.4)$ & $<0.005$ \\
CRP $(\mu \mathrm{g} / \mathrm{ml})$ & $4.1(0.6-75.0)$ & $11.8(1.1-75.0)$ & $<0.005$ \\
LBP $(\mu \mathrm{g} / \mathrm{ml})$ & $27.9(14.1-71.5)$ & $45.6(8.1-200.0)$ & $<0.005$ \\
sTNF-R55 $(\mathrm{ng} / \mathrm{ml})$ & $0.56(0.36-0.90)$ & $0.66(0.37-2.44)$ & $<0.05$ \\
sTNF-R75 $(\mathrm{ng} / \mathrm{ml})$ & $1.59(0.96-2.87)$ & $1.72(0.81-4.66)$ & NS \\
sIL-1RII $(\mathrm{ng} / \mathrm{ml})$ & $4.63(3.80-5.93)$ & $4.53(2.09-7.60)$ & NS \\
\hline
\end{tabular}

Data are median (range).

*Mann-Whitney U test.

+Value for 19 healthy controls.

$\mathrm{CRP}=\mathrm{C}$ reactive protein; $\mathrm{LBP}=$ lipopolysaccharide binding protein; $\mathrm{sTNF}-\mathrm{R}=$ soluble tumour necrosis factor receptor; sIL-1RII = soluble interleukin 1 receptor II; NS = non-significant.

Clear indications for a systemic inflammatory process in patients with stable COPD compared with healthy controls are shown in table 2. Significantly increased leucocyte counts and increased levels of CRP and LBP were found in the peripheral blood of the patient group. Increased levels of sTNF-R55 were seen but there was no difference in the levels of sTNF-R75 or sIL-1RII between patients with COPD and control subjects (table 2).

The effect of treatment on systemic inflammation in the patients with COPD was analysed. Maintenance medication consisted of oral or inhaled $\beta_{2}$ sympathicomimetics $(n=53)$, oral theophylline resulting in a plasma theophylline concentration within the therapeutic range $(8.3(5.0-16.4) \mathrm{mg} / \mathrm{ml} ; \mathrm{n}=35)$, inhaled ipratropium bromide $(n=49)$, oral glucocorticosteroids (7.50 (5.0-12.5 mg/day; $\mathrm{n}=26)$, and inhaled glucocorticosteroids $(n=45)$. Six of the 55 patients were using additional oxygen because of low resting arterial $\mathrm{PaO}_{2}$. No differences in systemic levels of CRP, LBP, sTNFRs, and sIL-1RII were observed between patients taking oral corticosteroids and those not doing so (data not shown), although the leucocyte count was increased in patients using oral glucocorticosteroids $(7.7(4.7-16.4) \times$ $10^{9} / 1$ v $\left.7.0(4.8-10.0) \times 10^{9} / 1 ; \mathrm{p}<0.05\right)$. The systemic levels of CRP, LBP, sTNF-Rs, and the leucocyte count were significantly increased in the subgroup of patients not using oral glucocorticosteroids compared with healthy controls. The other medications had no significant effects on levels of inflammatory mediators (data not shown), with the exception of an increased sTNF-R55 level with ipratropium bromide $(0.68 \quad(0.38-2.44) \mathrm{ng} / \mathrm{ml} \quad v \quad 0.50$ $(0.37-0.80) \mathrm{ng} / \mathrm{ml} \mathrm{p}<0.05)$ and reduced
sTNF-R75 level with inhaled glucocorticosteroids (1.53 (0.81-4.66) ng/ml v 1.90 (1.494.04) $\mathrm{ng} / \mathrm{ml} ; \mathrm{p}<0.05)$. No relationship was observed between $\mathrm{PaO}_{2}$ and levels of CRP, sTNF-R55, sTNF-R75, and leucocyte count, but levels of LBP were inversely related $(r=-0.317, \mathrm{p}=0.019)$. In order to analyse the effect of smoking behaviour on systemic inflammation, levels of inflammatory mediators in ex-smokers $(n=38)$ and current smokers $(n=16)$ were compared. No differences were observed with respect to leucocyte count and CRP, LBP, and sIL-1RII levels but levels of both sTNF-R55 and sTNF-R75 were significantly lower in current smokers (sTNF-R55: current smokers $(0.59 \quad(0.38-0.83) \mathrm{ng} / \mathrm{ml} v$ ex-smokers $0.68(0.37-2.08) \mathrm{ng} / \mathrm{ml}, \mathrm{p}<0.05$; sTNF-R75: current smokers 1.35 (0.812.10) $\mathrm{ng} / \mathrm{ml} v$ ex-smokers $1.74(0.94-4.21) \mathrm{ng} /$ $\mathrm{ml}, \mathrm{p}<0.05)$. No influence of sex on inflammatory mediators was detected (data not shown). In addition, no significant correlation could be found between the levels of systemic pro- or anti-inflammatory mediators and the lung function of patients (data not shown).

PATIENTS WITH AN EXACERBATION OF COPD Thirteen patients (nine men) with an exacerbation of the disease were studied. On day 1 $\mathrm{PaCO}_{2}$ was higher and $\mathrm{PaO}_{2}$ was lower than in patients with stable COPD. Ten of the 13 patients were current or ex-smokers. Only one patient had fever on the first day after admission. Standard medication was started immediately after admission (day 0). During the hospital stay nine patients were given additional oxygen. The median length of hospital stay was 12 (9-28) days. Nine of the patients were suffering from bacterial infection; three were colonised with Haemophilus influenzae as the sole pathogen whereas $H$ influenzae was combined with Pseudomonas sp and Moraxella $\mathrm{sp}$ in one, with other Gram negative organisms in two, with Pneumococcus sp in one, and with Pasteurella sp in one. One patient was colonised by Pseudomonas aeruginosa as the sole pathogen.

Levels of inflammatory mediators were measured on days 1, 3, 5, and 7 after admission. Both acute phase proteins were significantly reduced during treatment of the exacerbation (fig 1). Compared with day 1 , CRP levels were significantly reduced at day 3 and LBP levels at day 7 . In contrast, sIL-1RII levels increased progressively during treatment to day 5, after which they remained at the same level (fig 1). Treatment of the exacerbation also resulted in a significant increase in leucocyte count from day 1 to day 3 (fig 1). Both sTNFR55 and sTNF-R75 showed a temporary rise from day 1 to day 3 of treatment (sTNF-R55: day $1,0.57(0.39-0.87) \mathrm{ng} / \mathrm{ml} v$ day $3,0.66$ (0.48-1.18) ng/ml, p<0.05; sTNF-R75: day 1 , $1.30(1.05-2.10) \mathrm{ng} / \mathrm{ml} v$ day $3,1.55$ (1.242.94) $\mathrm{ng} / \mathrm{ml}, \mathrm{p}<0.05)$. The levels of both sTNF-R55 and sTNF-R75 at days 5 and 7 did not differ from those on day 1 (data not shown). 

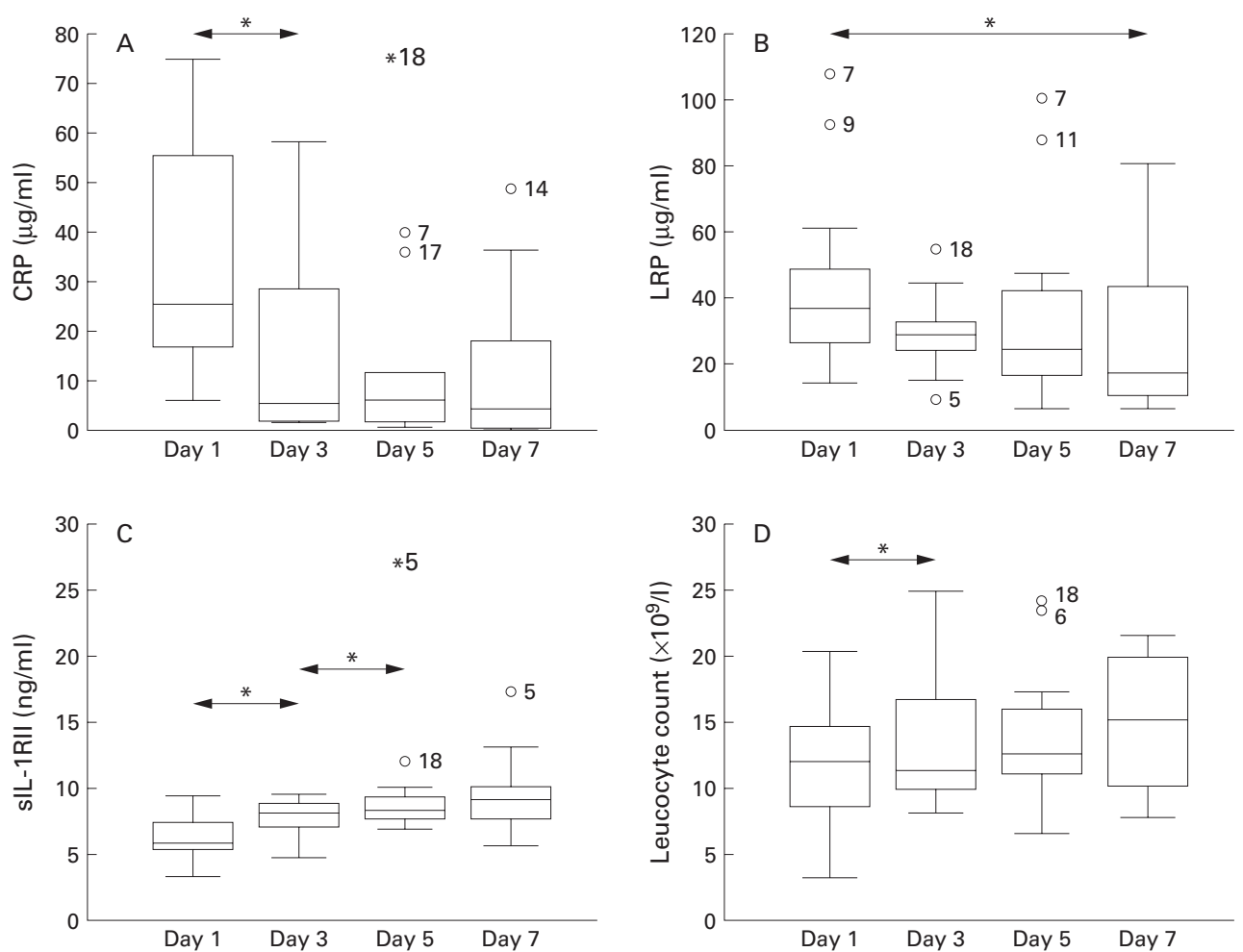

Figure 1 Decrease in (A) CRP and (B) LBP (B) and increase in (C) sIL1-RII and (D) leucocyte count during treatment of exacerbations of COPD. Blood was collected from patients $(n=13)$ on days $1,3,5$, and 7 after admission to the hospital for an acute disease exacerbation. Data are expressed as box plots showing the median, interquartile range, outliers, and extreme cases of individual variables (indicated by individual patient numbers). For statistical analysis the Wilcoxon signed rank test was used. The arrows represent significant differences $\left({ }^{\star} p<0.05\right)$.

No relationship was found between a positive bacterial culture and levels of inflammatory mediators. During the hospital stay a small but significant improvement was seen in lung function $\left(\mathrm{FEV}_{1} 0.84(0.56-1.52) 1\right.$ and $0.72(0.56-1.44) 1$ on days 7 and 3, respectively; $\mathrm{p}<0.05)$. In addition, subjective disease symptoms monitored by dyspnoea were reduced during the course of the disease. Further analysis of the changes in inflammatory mediators revealed that changes between days 1 and 7 in sIL-1RII levels were strongly correlated with changes between days 1 and 7 in leucocyte count $(r=0.74, \mathrm{p}=0.015)$.

\section{Discussion}

In this study the systemic levels of the soluble forms of both TNF-R55 and TNF-R75 and of IL-1RII, which could function as naturally occurring cytokine inhibitors, ${ }^{11}$ were analysed. The pro-inflammatory cytokines $\mathrm{TNF}$ and IL-1 are thought to play a central role in inflammatory processes, and increased levels of $\mathrm{TNF}$ have been reported in sputum and in the circulation of patients with COPD. ${ }^{2}{ }^{23}$ Furthermore, both TNF and IL-1 have been detected in bronchial submucosal cells in patients with chronic bronchitis, and during exacerbations the number of TNF positive cells is significantly increased. ${ }^{5}$ Although the chronic inflammatory state in COPD suggests an imbalance between pro- and anti-inflammatory mediators, to date there are no data on the levels of anti-inflammatory mediators in this disease. Results from this study show that sTNF-R55 levels were significantly increased in patients with stable COPD compared with controls, and sTNF-R75 levels also showed a tendency to increase, which is in agreement with the findings of previous studies. ${ }^{32}$ In vitro studies have revealed that shedding of TNF-R from the cell membrane is induced by proinflammatory mediators. ${ }^{15}$ In addition, increased levels of sTNF-Rs have been reported in various inflammatory diseases, ${ }^{24}$ indicating that increased levels of TNF-Rs can be considered as markers for an inflammatory process. In addition, both sTNF-Rs retain their ability to bind TNF and, when present in high concentrations, they block the biological activity of TNF. ${ }^{14}$ Since the increase in the level of TNF-Rs observed in the patients with stable COPD in this study was very mild, they are considered mainly as markers for a proinflammatory state.

The soluble form of IL-1RII is present in the circulation of healthy controls and in increased levels in sepsis. ${ }^{25}$ The high binding affinity of sIL-1RII for IL- $1 \beta^{13}$ implies that raised levels of sIL-1RII may serve to buffer the systemic action of IL-1. However, no differences in circulating sIL-1RII levels were found between patients with COPD in a stable condition and controls.

To monitor the systemic inflammatory response, the acute phase proteins CRP and LBP were measured and were found to be significantly increased in patients with stable COPD, in agreement with previous studies. ${ }^{36}$ The concept that stable COPD is characterised by a systemic inflammatory process is further supported by reports of increased circulating levels 
of IL-6 and raised counts of activated leucocytes in COPD. ${ }^{46}$ Moreover, the observation in this study of increased levels of proinflammatory mediators such as acute phase proteins, sTNF-Rs, and leucocyte count, together with no change in the levels of the anti-inflammatory mediator sIL-1RII, suggest an imbalance between pro- and antiinflammatory mediators in the circulation of patients with stable COPD.

Several factors are known to affect airway inflammation in COPD ${ }^{27}$ Increased circulating levels of leucocytes were observed in the subgroup of patients with stable COPD treated with oral corticosteroids, a drug which is known to have anti-inflammatory activity. This may reflect an increased survival time of cells resulting from an inhibitory action of steroids on neutrophil apoptosis ${ }^{28}$ However, in the subgroup of patients not using oral glucocorticosteroids increased systemic inflammation indicated by a raised leucocyte count and increased levels of soluble mediators was also present, which suggests that the systemic inflammatory process in COPD is not due solely to oral corticosteroid use. Hill et al reported a reduction in IL-8 levels in the sputum of patients with COPD who had stopped smoking compared with patients who were currently smoking. ${ }^{29}$ However, we found no effect of smoking on the systemic inflammatory profile in this study, with the exception of both the sTNF-Rs which were surprisingly reduced in current smokers compared with ex-smokers. $\mathrm{PaO}_{2}$ had no effect on the systemic inflammatory markers in our study, but Takabatake et $a l^{23}$ found an inverse correlation between systemic hypoxaemia and circulating TNF and TNF-Rs levels in patients with COPD. This discrepancy could be due to the fact that the patients in the latter study had more severe hypoxaemia than those in our study. Recent papers have reported a relation between bacterial load of patients with stable COPD and local inflammation as measured in sputum and BAL fluid. ${ }^{30}{ }^{31}$ Further studies are required to study the relationship between lower respiratory tract infection and systemic inflammation.

The events responsible for increased susceptibility to develop an exacerbation of COPD are poorly understood. Evidence indicates prominent changes in the inflammatory profile during exacerbations reflected by airway eosinophilia and increased levels of sputum proteins such as IL-6, IL-8, myeloperoxidase (MPO), elastase, and endothelin-1..$^{5-7} 10$ In addition, increased levels of systemic inflammatory markers such as CRP, IL-6, fibrinogen, eosinophilic cationic protein (ECP), and MPO have been reported. ${ }^{8}{ }^{9}$ Antibiotic treatment of patients with acute bacterial exacerbations resulted in a reduction in CRP levels. ${ }^{6} \mathrm{We}$ also found that treatment of an exacerbation resulted in a decline in the levels of both acute phase proteins CRP and LBP. The levels of both sTNF-Rs, however, showed only moderate changes and thus seemed not to be involved in the pathogenesis of the exacerbation. Furthermore, in this study it is reported for the first time that the levels of the antiinflammatory mediator sIL-1RII increased significantly during treatment of the exacerbation, implying that this could contribute to clinical improvement in patients with COPD.

Standard medication during treatment of an exacerbation in our hospital during the time of the study included intravenous administration of prednisolone. In vitro experiments have shown that exposure of cells to the steroid analogue dexamethasone resulted in enhanced membrane expression of IL-1RII followed by augmented release of the receptor over a period of 18-24 hours. ${ }^{32}$ These findings, and the increase in sIL-1RII levels from days 1 to 5 of treatment, strongly suggest that the continuous administration of corticosteroids is responsible for the increase in sIL-1RII levels and may thus contribute to the clinical improvement of these patients. However, further research is required to test this hypothesis. In addition, the increased leucocyte count observed in the exacerbated patients could be due to the administration of corticosteroids as part of the treatment procedure, as has been discussed earlier.

It cannot be determined from this study whether systemic levels of sIL-1RII are derived from the lungs or are produced in the blood. Membrane bound IL-1RII has been identified on B lymphocytes, monocytes, PMN, and bone marrow cells, ${ }^{33}$ whereas no expression of this receptor could be detected on lung epithelial cell lines. ${ }^{34}$ The strong relationship between systemic leucocyte count and sIL-1RII levels suggests that this mediator is derived from blood leucocytes. Further studies are required to analyse the source of sIL-1RII and to investigate its biological effects, both local and systemic.

In conclusion, data presented in this study suggest an imbalance in levels of pro- and antiinflammatory mediators in the peripheral blood of patients with clinically stable COPD. Furthermore, treatment of exacerbations was shown to be associated with a reduction in acute phase proteins CRP and LBP and in an increase in sIL-1RII levels, which could be responsible for the observed clinical improvement.

The authors thank Ingrid Vanderhoven for collection of patient samples during disease exacerbations.

Funding: This work was supported by a grant of GlaxoWellcome, The Netherlands, and by European Commission BIO4CT97-2107.

1 Barnes PJ. Medical progress: chronic obstructive pulmonary disease. N Engl F Med 2000;343:269-80.

2 Keatings VM, Collins PD, Scott DM, et al. Differences in interleukin-8 and tumor necrosis factor-alpha in induced sputum from patients with chronic obstructive pulmonary disease or asthma. Am $\mathcal{F}$ Respir Crit Care Med 1996;153: $530-4$.

3 Schols AM, Buurman WA, Staal van den Brekel AJ, et al. Evidence for a relation between metabolic derangements and increased levels of inflammatory mediators in a subgroup of patients with chronic obstructive pulmonary disease. Thorax 1996;51:819-24.

4 Noguera A, Busquets X, Sauleda J, et al. Expression of adhesion molecules and $G$ proteins in circulating neutrophils in chronic obstructive pulmonary disease. $\mathrm{Am} \mathcal{F}$ trophils in chronic obstructive pulmo

5 Saetta M, Di Stefano A, Maestrelli P, et al. Airway Saetta M, Di Stefano A, Maestrelli P, et al. Airway
eosinophilia in chronic bronchitis during exacerbations. Am 7 Respir Crit Care Med 1994;150:1646-52.

6 Hill AT, Campbell EJ, Bayley DL, et al. Evidence for excessive bronchial inflammation during an acute exacerbation 
of chronic obstructive pulmonary disease in patients with alpha-1-antitrypsin deficiency (PiZ). Am $\mathcal{7}$ Respir Crit Care Med 1999;160:1968-75.

7 Bhowmik A, Seemungal TAR, Sapsford RJ, et al. Relation of sputum inflammatory markers to symptoms and lung function changes in COPD exacerbations. Thorax 2000;55 114-20.

8 Fiorini G, Crespi S, Rinaldi M, et al. Serum ECP and MPO are increased during exacerbations of chronic bronchitis with airway obstruction. Biomed Pharmacother 2000;54 274-8.

9 Wedzicha JA, Seemungal TA, MacCallum PK, et al. Acute exacerbations of chronic obstructive pulmonary disease are accompanied by elevations of plasma fibrinogen and serum IL-6 levels. Thromb Haemost 2000;84:210-5.

10 Roland M, Bhowmik A, Sapsford RJ, et al. Sputum and plasma endothelin-1 levels in exacerbations of chronic obstructive pulmonary disease. Thorax 2001;56:30-5.

11 Dinarello CA. Role of pro- and anti-inflammatory cytokines during inflammation: experimental and clinical findings. $\mathcal{F}$ Buring inflammation: experimental and clinic

12 Colotta F, Re F, Muzio M, et al. Interleukin-1 type II receptor: a decoy target for IL-1 that is regulated by IL-4

13 Arend WP, Malyak M, Smith MF Jr, et al. Binding of IL-1 alpha, IL-1 beta, and IL-1 receptor antagonist by soluble IL-1 receptors and levels of soluble IL-1 receptors in synovial fluids. F Immunol 1994;153:4766-74

14 Hale KK, Smith CG, Baker SL, et al. Multifunctional regulation of the biological effects of TNF-alpha by the soluble type I and type II TNF receptors. Cytokine 1995;7:26-38.

15 Bigda J, Holtmann H. TNF receptors: how they function and interact. Arch Immunol Ther Exp Warsz 1997;45:26370 .

16 COPD Guidelines Group of the Standards of Care Committee of the BTS. BTS guidelines for the management of chronic obstructive pulmonary disease. Thorax 1997;52(Suppl 5):S1-28.

17 Quanjer PH, Tammeling GJ, Cotes JE, et al. Lung volumes and forced ventilatory flows. Report Working Party Standand forced ventilatory flows. Report Working Party Standardization of Lung Function Tests, European Community Respiratory Society. Eur Respir F Suppl 1993;16:5-40.

18 Grant S, Aitchison T, Henderson E, et al. A comparison of the reproducibility and the sensitivity to change of visua analogue scales, Borg scales, and Likert scales in norma subjects during submaximal exercise. Chest 1999;116 1208-17.

19 Leeuwenberg JF, Jeunhomme TM, Buurman WA. Slow release of soluble TNF receptors by monocytes in vitro. $\mathscr{f}$ Immunol 1994;152:4036-43.

20 Froon AH, Dentener MA, Greve JW, et al. Lipopolysaccharide toxicity-regulating proteins in bacteremia. F Infect $\mathrm{Di}$ 1995;171:1250-7.
21 Colotta F, Saccani S, Giri JG, et al. Regulated expression and release of the IL-1 decoy receptor in human mononuclear phagocytes. F Immunol 1996;156:2534-41.

22 Altman DG, Gore SM, Gardner MJ, et al. Statistical guidelines for contributors to medical journals. Br Med f Clin Res Ed 1983;286:1489-93

23 Takabatake N, Nakamura $\mathrm{H}$, Abe S, et al. The relationship between chronic hypoxemia and activation of the tumor necrosis factor-alpha system in patients with chronic obstructive pulmonary disease. Am f Respir Crit Care Med 2000;161:1179-84.

24 van der Poll T, Jansen J, van Leenen D, et al. Release of soluble receptors for tumor necrosis factor in clinical sepsis and experimental endotoxemia. F Infect Dis 1993;168:95560.

25 Giri JG, Wells J, Dower SK, et al. Elevated levels of shed type II IL-1 receptor in sepsis. Potential role for type II receptor in regulation of IL-1 responses. F Immunol 1994;153:5802-9.

26 Yasuda N, Gotoh K, Minatoguchi S, et al. An increase of soluble Fas, an inhibitor of apoptosis, associated with progression of COPD Respir Med 1998;92:993-9.

27 Hill A, Gompertz S, Stockley R. Factors influencing airway inflammation in chronic obstructive pulmonary disease. Thorax 2000;55:970-7.

28 Meagher LC, Cousin JM, Seckl JR, et al. Opposing effects of glucocorticoids on the rate of apoptosis in neutrophilic and eosinophilic granulocytes. F Immunol 1996;156:4422-8.

29 Hill AT, Bayley DL, Campbell EJ, et al. Airways inflammation in chronic bronchitis: the effects of smoking and alpha-1-antitrypsin deficiency. Eur Respir $f$ 2000;15:88690

30 Hill AT, Campbell EJ, Hill SL, et al. Association between airway bacterial load and markers of airway inflammation in patients with stable chronic bronchitis. Am F Med 2000; 109:288-95.

31 Soler N, Ewig S, Torres A, et al. Airway inflammation and bronchial microbial patterns in patients with stable chronic obstructive pulmonary disease. Eur Respir F 1999;14:101522

32 Orlando S, Sironi M, Bianchi G, et al. Role of metalloproteases in the release of the IL-1 type II decoy receptor. $f$ Biol Chem 1997;272:31764-9.

33 McMahan CJ, Slack JL, Mosley B, et al. A novel IL-1 receptor, cloned from B cells by mammalian expression, is expressed in many cell types. EMBO f 1991;10:2821-32.

34 Coulter KR, Wewers MD, Lowe MP, et al. Extracellular regulation of interleukin (IL)-1beta through lung epithelial cells and defective IL-1 type II receptor expression. Am $\mathcal{F}$ Respir Cell Mol Biol 1999;20:964-75. 